\title{
Measles in Pregnancy: Evaluation of 19 Cases
}

\author{
Gebelikte Kızamık: 19 Hastanın Değerlendirilmesi
}

\author{
(1) Hasan KARSEN ${ }^{1}$, (1) Tuba DAMAR ÇAKIRCA ${ }^{2}$, (1) Azize Sezin ŞEYHANOĞLU ${ }^{3}$, (1) Mustafa DEMiR ${ }^{4}$ \\ ${ }_{1}^{1}$ Harran University Faculty of Medicine, Department of Infectious Diseases and Clinical Microbiology, Şanlıurfa, Turkey \\ 2Şanlıurfa Training and Research Hospital, Clinic of Infectious Diseases and Clinical Microbiology, Şanlıurfa, Turkey \\ ${ }^{3}$ Bingöl Maternity and Children Diseases Hospital, Clinic of Infectious Diseases and Clinical Microbiology, Bingöl, Turkey \\ ${ }^{4}$ Anka Hospital, Clinic of Obstetrics and Gynecology, Gaziantep, Turkey
}

\section{Abstract}

Introduction: This study aims to evaluate 19 pregnant patients with measles and determine the impact of the disease on maternal and fetal outcomes.

Materials and Methods: Medical reports were used to assess the demographic characteristics, clinical courses, and laboratory findings of 19 pregnant patients with measles, as well as fetal outcomes.

Results: All of the patients had fever, rashes, and cough, and they were all admitted to the hospital. The serious complications were diarrhea (52.6\%, $n=10)$, elevated liver enzymes $(31.6 \%, n=6)$, and pneumonia $5.3 \%(n=1)$, respectively; 17 out of 19 pregnancies ended uneventfully. One pregnancy resulted in miscarriage, while the other ended with premature labor. There were no cases of congenital measles, neonatal complications, or maternal mortality.

Conclusion: The clinical course of measles in pregnant women was generally favorable, according to our results. On the other hand, the disease could lead to deleterious effects for both fetal and maternal outcomes. To improve the perinatal outcome, pre-gestational high vaccine coverage should be achieved.

Keywords: Measles, pregnancy, perinatal outcome, vaccination

\section{Öz}

Giriş: Bu yazıda kızamık enfeksiyonu olan 19 gebe hastanın değerlendirilmesi ve hastalığın maternal ve fetal sonuçlar üzerindeki etkisinin belirlenmesi amaçlandı.

Gereç ve Yöntem: Kızamık enfeksiyonu olan 19 gebe hastanın demografik özellikleri, klinik seyirleri ve laboratuvar bulguları ile fetal sonuçları hastane bilgi sistemi ve hasta dosyaları retrospektif olarak incelenerek elde edildi.

Bulgular: Hastaların tamamında ateş, döküntü ve öksürük mevcuttu ve tüm hastalar hastanede yatarak takip edildi. Ciddi komplikasyonlar sırasıyla diyare $(\% 52,6, n=10)$, karaciğer enzimlerinde artış $(\% 31,6, n=6)$ ve pnömoni \%5,3 $(n=1)$ olarak saptandı. 19 gebelikten 17'si komplikasyonsuz sonuçlandı. Gebeliklerden biri düşük, diğeri ise erken doğumla sonuçlandı. Konjenital kızamık enfeksiyonu, yenidoğan komplikasyonları veya maternal mortalite gözlenmedi.

Sonuç: Sonuçlarımız, gebe kadınlarda kızamığın klinik seyrinin genel olarak olumlu olduğunu göstermektedir. Bununla birlikte, hastalık hem fetal hem de maternal komplikasyonlar açısından riskli olabilir. Gebelik döneminde kızamığa bağlı mortalite ve morbiditelerin azaltılması için, doğurganlık çağındaki kadınlarda gebelik öncesi aşılamanın tamamlanması gerekmektedir.

Anahtar Kelimeler: Kızamık, gebelik, perinatal sonuç, aşılama

Cite this article as: Karsen H, Damar Çakırca T, Şeyhanoğlu AS, Demir M. Measles in Pregnancy: Evaluation of 19 Cases. Mediterr J Infect Microb Antimicrob. $2021 ; 10: 31$.

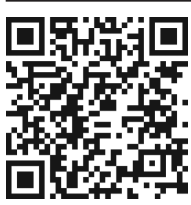

Address for Correspondence/Yazışma Adresi: Tuba Damar Çakırca MD, Şanlıurfa Training and Research Hospital, Clinic of

Infectious Diseases and Clinical Microbiology, Şanlıurfa, Turkey

Phone: +90 4143171717 E-mail: dr.tubadamar@gmail.com

Received/Geliş Tarihi: 23.03.2021 Accepted/Kabul Tarihi: 09.05.2021 ORCID ID: orcid.org/0000-0002-1706-230X

- Copyright 2021 by the Infectious Diseases and Clinical Microbiology Specialty Society of Turkey

Mediterranean Journal of Infection, Microbes and Antimicrobials published by Galenos Yayinevi.

Presented in: An oral presentation was made at the $7^{\text {th }}$ Turkey EKMUD Scientific Platform held in Antalya from April 3 to 7 April. 


\section{Introduction}

Measles, acute highly contagious disease, is caused by the enveloped rubeola virus from the family of Paramyxoviridae. Fever, cough, conjunctivitis, coryza, malaise, and maculopapular rashes are the most common symptoms, which pervade in a centrifugal form. On the buccal mucosa, Koplik spots appear as a pathognomonic sign, providing the early diagnosis. The most common complications during the disease are diarrhea, otitis media, and pneumonia ${ }^{[1,2]}$.

Pregnant individuals are at high risk of detrimental consequences due to the measles. Despite the fact that no birth defects or malformations linked to measles have been reported to date, poor perinatal outcomes, such as premature labor, stillbirth, low-birth weight neonates, or abortions are known to occur ${ }^{[2,3]}$. There were limited studies in the literature about the effects of measles on pregnant women. More information with regard to the course of disease during pregnancy is needed in this context. As a result, we set out to study 19 pregnant patients who were diagnosed with measles during the epidemic surged in our country between 2012 and 2014, in order to assess the disease's effect on maternal and fetal outcome.

\section{Materials and Methods}

This retrospective and descriptive study was conducted in a tertiary care hospital's department of Infectious Diseases. During the epidemic in Turkey between January 2012 and December 2014, 19 pregnant patients were admitted to our inpatient clinic and diagnosed with measles. Medical records were used to assess demographic characteristics, gestational ages, vaccination status or measles history, clinical findings and courses, and laboratory findings and results of the patients, as well as fetal outcomes.

Clinical examination and measles virus immunoglobulin $M$ antibody positivity (enzyme-linked immunosorbent assay) were used to make the diagnosis. The faculty of Medical Ethics Committee granted authorization with the protocol number of 17.06.12.

\section{Statistical Analysis}

Statistical Package for the Social Sciences version 21.0 (Chicago, IL, USA) was used to perform the data analysis. Categorical variables were presented as numbers and percentage, whereas continuous variables were presented as mean \pm standard deviation.

\section{Results}

One of the 19 patients was a Syrian refugee, while the others were Turkish citizens. The ages of the patients were between 19 and 34 years (mean, 25.1 \pm 3.9 ), and the gestational ages at the admission were between four and 37 weeks (mean, 19.5 \pm 10.9 ) (Table 1); 12 out of 19 patients were unaware of their vaccination status, while seven of them were not vaccinated. None of the 19 patients had ever had measles.

All of patients had fever, maculopapular rashes, and cough, and they were all admitted to the hospital for closer monitoring. Sixteen patients developed rashes their faces, while others developed rashes on their backs, trunks, and necks. The period between the onset of symptoms and hospital admission was between three and seven days, with a mean of $4.63 \pm 1.54$ days. Five of 19 patients (26.3\%) had also Koplik spots.

The most common complications were diarrhea $(52.6 \% ; n=10)$, followed by otitis media $(36.8 \% ; n=7)$, and pneumonia $(5.3 \%$; $\mathrm{n}=1)$. Six patients had elevated liver enzymes $(31.6 \%)$, and one of them had obstructive jaundice with a high level of bilirubin, alkaline phosphates, and gamma glutamyl transferase.

The mean of leukocyte values was $7,507 \times 10^{3} / \mu \mathrm{l}(2,260$ $\left.13,000 \times 10^{3} / \mu \mathrm{l}\right)$, and the mean of platelet values was $201 \times 10^{3} /$ $\mathrm{mm}^{3}\left(111-286 \times 10^{3} / \mathrm{mm}^{3}\right)$. Two patients had thrombocytopenia, one patient had leukocytosis, and one patient had leukopenia.

Regarding the fetal outcomes, one fetus was lost due to miscarriage at the gestational age of 19 weeks, while one baby was born prematurely at the gestational age of 36 weeks. There

Table 1. General characteristics and perinatal outcomes of 19 patients

\begin{tabular}{ll}
\hline General characteristics & $25.1 \pm 3.9$ \\
\hline Age (mean \pm SD) & $19.5 \pm 10.9$ \\
\hline Gestational age (mean \pm SD) & $19(100)$ \\
\hline Measles-related signs and symtoms & $19(100)$ \\
\hline Fever and rash, $\mathrm{n}(\%)$ & $15(78.9)$ \\
\hline Cough, $\mathrm{n}(\%)$ & $5(26.3)$ \\
\hline Sputum, $\mathrm{n}(\%)$ & $10(52.6)$ \\
\hline Koplik sign, $\mathrm{n}(\%)$ & $7(36.8)$ \\
\hline Maternal complications & $1(5.3)$ \\
\hline Diarrhea, $\mathrm{n}(\%)$ & $6(31.6)$ \\
\hline Otitis media, $\mathrm{n}(\%)$ & $4(3-7)$ \\
\hline Pneumonia, $\mathrm{n}(\%)$ & \\
\hline Elevated liver enzymes, $\mathrm{n}(\%)$ & $0(0)$ \\
\hline Length of symptoms (median, minimum-maximum) & $7(36.8)$ \\
\hline Vaccine status & $12(63.1)$ \\
\hline Yes, $\mathrm{n}(\%)$ & $1(5.3)$ \\
\hline No, $\mathrm{n}(\%)$ & $1(5.3)$ \\
\hline Unknown, $\mathrm{n}(\%)$ & \\
\hline Perinatal outcome & \\
\hline Spontaneous abortion, $\mathrm{n}(\%)$ & \\
\hline Premature labor, $\mathrm{n}(\%)$ & \\
\hline SD: Standard deviation & \\
\hline
\end{tabular}


were no congenital malformations, stillbirths, or intrauterin fetal deaths. Out of one fetus that was lost with abortion, all newborns were healthy and free of measles, and no postnatal prophylaxis against measles was administered. All patients were recovered with supportive therapy of antipyretics and fluid therapy, and all pregnancies ended uneventfully without any maternal mortality.

\section{Discussion}

Measles still remains one of the world's and our country's leading health problem. It can affect people of various ages, including pregnant women. Immune suppression arising during pregnancy can make pregnant women more susceptible to the disease. As a result, the course of measles in pregnant women is more lethal and complicated than in non-pregnant women ${ }^{[4,5]}$. However, there is limited information on measles infection in pregnant woman.

There are a few case series on measles in pregnancy, including eight ${ }^{[6]}, 13^{[7]}, 40^{[3]}, 55^{[5]}$, and 61 cases $^{[8]}$, and all of which were performed before 2015. In this study, we reviewed 19 pregnant patients with measles having different complications. We hospitalized all patients to ensure close follow-up as we were concerned that patients would be able to comply droplet isolation due to their low educational background. As a result, the number of patients in our study who were admitted to the hospital was higher than the rates reported in the literature ${ }^{[3,5,6]}$.

In comparison with earlier reports, we identified similar rates of clinical syptoms and complications compared in terms of fever, rashes, cough, and diarrhea in the present study, but a reduced rate of pneumonia. In a case series by Chiba et al. ${ }^{[6]}$, all patients had Koplik spots with maculopapular rashes and a $62.5 \%$ fever rate. Pneumonia was seen in $25 \%$ of patients $(n=2)$, but diarrhea was not reported. Similar to our results, Ogbuanu et al. ${ }^{[5]}$ reported that all of their patients had fever and rashes, as well as 50 patients (91\%) who had cough and $33(60 \%)$ had diarrhea. In our study, however, only one patient (5.3\%) had pneumonia, whereas nearly half of their patients had pneumonia $(n=22,40 \%)$. In a recent study from France, $84 \%$ of the 13 patients had fever, and all patients had maculopapular rashes. In addition, 4 of 13 patients had pneumonia, and seven had a cough ${ }^{[5-7]}$.

We found the proportion of patients with elevated liver enzymes as $31.6 \%$, in consistent with a recent study $y^{[7]}$. Apart from one patient with obstructive jaundice, other elevations of liver enzymes were mild and recovered without advance complication. Furthermore, Ali and Albar reported elevated liver enzymes in 26 of their patients (65\%), and Atmar et al..$^{[9]}$ observed the same complication in seven patients (54\%), which are the highest rates of transaminase increases in the related literature ${ }^{[3]}$.
Otitis media is one of the most common measles complication, with a prevalence of $7 \%$ and a high prevalence in children ${ }^{[2]}$. Surprisingly, pregnant cases (36.8\%) had otitis media in our case series, despite the fact that we could not reach such data regarding this complication in previous studies held on pregnancies.

Neurologic problems, such as acute disseminated encephalomyelitis, measles inclusion body encephalitis, and subacute sclerosing panencephalitis are another comparably rare but life-threatining complications ${ }^{[10]}$. Encephalitis as a measles-related complication was reported in three pregnant patients (one of whom died) of 55 case series ${ }^{[5]}$. Another study found that one pregnant patient with encephalitis died as a result of this complication ${ }^{[8]}$. Fortunately, none of our patients had encephalitis.

In our case series, there were no cases of congenital measles, neonatal complications, or maternal mortality. One of the fetuses, however, was born prematurely, while the other labor ended with fetal loss. Other fetuses were born healthy and at term throughout the follow-up. A recent study from Sudan revealed high maternal mortality rate of $18 \%$, as well as high rates of abortion (11.3\%), prematurity $(7.5 \%)$, and stillbirth $(5.7 \%)^{[8]}$. Being a low-income country may explain the high case mortality rate and unfavorable perinatal outcome. Another descriptive study reported that $31 \%$ of 58 gestations ended prematurely, with 13 cases of premature labor and five cases of miscarriage ${ }^{[11]}$. Casalegno et al. ${ }^{[7]}$, on the other hand, reported fetal and maternal outcomes that were similar to ours.

There is no proven treatment of measles like other viral disease apart from supportive care, and all of our patients recovered with antipyretics and fluid therapy.

When the measles develops during pregnancy, the course of disease may change. Fetal anomaly is not observed in measles. Even though our patients recovered with low morbidity and no mortality, emergence of measles in pregnancy leads to higher maternal mortality and complications, as well as worse perinatal outcome $^{[11]}$. Because the measles vaccine is contraindicated during pregnancy ${ }^{[12]}$ and controlling the disease after it has emerged is difficult, it poses high importance to prevent transmission of measles among pregnant women.

There are some limitations to this study. First, some data were missing due to the retrospective design. Second, we did not include non-pregnant measles patients or healty pregnant individuals as control groups in order to evaluate the effect of the disease on pregnancy. Third was the insufficient follow-up of babies after being discharged from the hospital, which made it difficult to see the long-term effects of measles. 


\section{Conclusion}

In conclusion, it is important to take precautions before gestation for child-bearing population, and attempts should be made to increase vaccine coverage in the society. Furthermore, early diagnosis, close observation, and proper treatment of complications alongside supportive therapy will improve the perinatal outcome.

\section{Ethics}

Ethics Committee Approval: This study was approved by the Local Ethics Committee of Harran University Faculty of Medicine (date: 8.06.2017, protocol number: 17.06.12).

Informed Consent: Retrospective study.

Peer-review: Externally peer-reviewed.

\section{Authorship Contributions}

Surgical and Medical Practices: H.K., A.S.Ş., M.D., Concept: H.K., T.D.Ç., Design: H.K., T.D.Ç., A.S.Ş., Data Collection or Processing: H.K., T.D.Ç., A.S.Ş., M.D., Analysis or Interpretation: H.K., T.D.Ç., A.S.Ş., M.D., Literature Search: H.K., T.D.Ç., A.S.Ş., M.D., Writing: H.K., T.D.Ç.

Conflict of Interest: No conflict of interest was declared by the authors.

Financial Disclosure: The authors declared that this study received no financial support.

\section{References}

1. Moss WJ. Measles. Lancet. 2017;390:2490-502.

2. Measles (Rubeola). Centers for Disease Control and Prevention. Last Accessed Date: 15.06.2021 Available from: https://www.cdc.gov/measles/ index.html

3. Ali ME, Albar HM. Measles in pregnancy: maternal morbidity and perinatal outcome. Int J Gynaecol Obstet. 1997;59:109-13.

4. Rota PA, Moss WJ, Takeda M, de Swart RL, Thompson KM, Goodson JL. Measles. Nat Rev Dis Primers. 2016;2:16049.

5. Ogbuanu IU, Zeko S, Chu SY, Muroua C, Gerber S, De Wee R, Kretsinger K, Wannemuehler K, Gerndt K, Allies M, Sandhu HS, Goodson JL. Maternal, fetal, and neonatal outcomes associated with measles during pregnancy: Namibia, 2009-2010. Clin Infect Dis. 2014;58:1086-92.

6. Chiba ME, Saito $M$, Suzuki $N$, Honda $Y$, Yaegashi N. Measles infection in pregnancy. J Infect. 2003;47:40-4.

7. Casalegno JS, Huissoud C, Rudigoz R, Massardier J, Gaucherand P, Mekki Y. Measles in pregnancy in Lyon France, 2011. Int J Gynaecol Obstet. 2014;126:248-51.

8. Ali AA, Abdelhameed 0 , Abdallah TM. Case-fatality rate associated with measles during pregnancy in Kassala, eastern Sudan. Int J Gynaecol Obstet. 2014;124:261-2.

9. Atmar RL, Englund JA, Hammill H. Complications of measles during pregnancy. Clin Infect Dis. 1992;14:217-26.

10. Griffin DE. Measles virus and the nervous system. Handb Clin Neurol. 2014;123:577-90.

11. Eberhart-Phillips JE, Frederick PD, Baron RC, Mascola L. Hamilelikte Kızamık: 58 vakanın tanımlayıcı bir çalışması. Obstet Gynecol. 1993;82:797-801.

12. Kumar D, Sabella C. Measles: Back again. Cleve Clin J Med. 2016;83:340-4. 